\title{
Editorial: The AESOP best PhD Paper Prize
}

Elisabete Silva PhD, FRICS, RTPI

Senior lecturer, Department of Land Economy, University of Cambridge, Cambridge, UK

The Association of European Schools of Planning (AESOP) was founded in 1987 by a renowned group of academics from European Universities: Patsy Healey (Newcastle, UK), Klaus R. Kunzmann (Dortmund, Germany), David Massey (Liverpool, UK), Dieter Frick (Berlin, Germany), Giorgio Piccinato (Venice, Italy), Dieter Bökemann (Vienna, Austria), Willy Schmid (Zürich, Switzerland), Andreas Faludi (Amsterdam, the Netherlands), Jean-Claude Hauvuy (Paris, France) and Luigi Mazza (Turin, Italy).

The formal charter establishing AESOP was signed in Dortmund, Germany, in 1987 and had the following objectives

- to represent the interest of planning schools in Europe in national and international administrations and organisations, particularly within Europe

- to promote the development of teaching and research in the field of planning

- to facilitate co-operation and exchange between planning schools in Europe, and to encourage the harmonisation and equivalence of their degrees

- to articulate a European dimension within planning education as part of the process of institutional co-operation and integration within Europe, bearing in mind also the prospect of increasing professional mobility within Europe

- to foster and enrich higher education in planning across Europe by mutual support, including facilitating dialogue, exchange visits and the spread of information

- to defend the cause of expanding and enhancing higher education in planning

- to promote a progressive approach to planning education in schools of planning by experts with a rounded view against rival claims from older-established academic units and from other disciplines and professions.

Now with more than 300 member schools around Europe, AESOP is the leading association for planning schools and its researchers. Besides the annual congress, AESOP organises multiple activities and working groups, also focusing on the development of $\mathrm{PhD}$ students by delivering the AESOP $\mathrm{PhD}$ Workshop and supporting a working group called the AESOP YA network (addressed at young academic planners who have recently entered the academic world: $\mathrm{PhD}$ students, postdocs or people starting in academic positions).

The AESOP website is the key platform to exchange information and link all embers (www.aesop-planning.eu).

All AESOP member schools and committees at AESOP go to extreme lengths to make sure that our PhD students and new academics are welcomed into the community by helping to develop their career and research interests. Therefore, it made a lot of sense to create a prize that supported $\mathrm{PhD}$ student publication.

Urban Design and Planning (UDP) took that challenge on board and has been pivotal in the promotion of $\mathrm{PhD}$ research through publication of $\mathrm{PhD}$ students papers presented at the annual AESOP congress. Every year UDP accepts the nominations of the committee created for the effect (a group of $\mathrm{PhD}$ students that promote and screen the submitted papers) that identifies the winner and the second and third place. A monetary prize, together with access to ICE journals/papers, and highlights in the websites of AESOP and UDP seem welldeserved awards.

This prize that was created for $\mathrm{PhD}$ students and managed by $\mathrm{PhD}$ students has been a success. Among dozens of $\mathrm{PhD}$ papers submitted to the AESOP conference of 2014 the following were shortlisted as prize winners.

- First place and BPP winner: Ioanna Katapadi for the paper entitled 'Perceiving heritage: the case of Greek traditional settlements'.

- First runner up: Dana Shevah for the paper entitled 'Planning and community in a complex/involved/tangled space'.

- Second runner up: Daniel Durrant for the paper entitled 'Why does it have to go so bloody fast?' Speed as a problematic feature of High Speed Rail'.

However, many more papers ended up not having an award but were also of very high quality. The solution was to advise authors to submit the remaining top papers to UDP so that all good papers could go also through the peer-review process. 
This issue of UDP publishes some of the top papers that were submitted to us by way of the AESOP best PhD paper prize.

- 'Community participation on the fringe of practice' (Shevah and Kallus, 2015).

- 'Examining awareness of heritage in Greek traditional settlements' (Katapadi, 2015).

- 'Towards an integrated energy landscape' (de Boer and Zuidema, 2015).

- 'The controversial discourse on speed in the case of HS2' (Durrant, 2015).

Aside from these four papers submitted to AESOP though the best $\mathrm{PhD}$ paper at last year's AESOP congress, we also included one more paper by Leonid Lavrov and Fedor Perov 'The landscape development of Saint Petersburg (1853-2003)' (Lavrov and Perov, 2015).

From the team at UDP, our sincere congratulations go to the winners of last year's AESOP congress best $\mathrm{PhD}$ papers: Ioanna Katapadi, Dana Shevah and Daniel Durrant. Our congratulations also go to all other PhD students that submitted their papers, including the ones published in this issue by Dana Shevah, Rachel Kallus, Ioanna Katapidi, Jessica de Boer, Christian Zuidema and Daniel William Durrant. And finally, our congratulations go to all authors (including Leonid
Lavrov and Fedor Perov whose paper is published in this issue) that submit on a regular basis full papers to be reviewed and published in UDP.

\section{REFERENCES}

de Boer J and Zuidema C (2015) Towards an integrated energy landscape. Proceedings of the Institution of Civil Engineers - Urban Design and Planning 168(5): 231-240, http://dx.doi.org/10.1680/udap.14.00041.

Durrant DW (2015) The controversial discourse on speed in the case of HS2. Proceedings of the Institution of Civil Engineers - Urban Design and Planning 168(5): 241-250, http://dx.doi.org/10.1680/udap.14.00050.

Katapadi I (2015) Examining awareness of heritage in Greek traditional settlements. Proceedings of the Institution of Civil Engineers - Urban Design and Planning 168(5): 251-258, http://dx.doi.org/10.1680/udap.14.00040.

Lavrov L and Perov F (2015) The landscape development of Saint Petersburg (1853-2003). Proceedings of the Institution of Civil Engineers - Urban Design and Planning 168(5): 259-266, http://dx.doi.org/10.1680/udap.15.00016.

Shevah D and Kallus R (2015) Community participation on the fringe of practice. Proceedings of the Institution of Civil Engineers - Urban Design and Planning 168(5): 223-230, http://dx.doi.org/10.1680/udap.14.00039. 